\title{
Effect of Educational Training Program for Mothers about their Cancer Children Care and its Effect on Children Health Status
}

\author{
Doaa Bahig Anwr Akl., Nabilla Hassan Ali Abdella., Amal Ahmed Khalil Morsy., \\ Momahmed Mohamed Ahmed Elmazahy \\ Assist lecture of pediatric nursing -Faculty of Nursing University Aswan University-; \\ Lecture of pediatric nursing; Prof of pediatric nursing- Faculty of Nursing Port Said \\ University; Prof of pediatric medicin-al Azhar University
}

\begin{abstract}
Background: Cancer diagnosis and its treatment highly affects negatively on health -related quality of life of children with cancer in physical, social, psychological, and cognitive dimensions in addition to put their care giver in a challenging situation.The aim: of this study was to evaluate the effect of educational training program for mothers about care of their children with cancer and its effect on children health status. Quasi-experimental research design was used in the study, a convenient sample of $\mathbf{5 0}$ mothers and their children with cancer at inpatient and out- patient departments at Oncology Institute in Mansoura City for six months from November 2013 to April 2014.The tools: of data collection were an interview questionnaire formto collect data about socio-demographic characteristics for studied mothers and their children, assessment of knowledge\& reported practice related childhood cancer and chemotherapy sheet and assessment of children health status scale. The results: revealed that There were statistically significant improvements in mother's knowledge and reported practice with $\mathrm{p}$. value $\mathrm{P}<0.001$.Subsequently, the results lead to a positive impact on their children's health status (physical, psychological, and social status), while there were no statistically significant improvement in children school achievement and their self- care .The study recommended: periodic or continuoustraining program should be applied for mothers and their child in the pediatric oncology departments to improve their knowledge and practice about childhood cancerwhich can increase improving in physical, psychological and social dimensions for children and subsequently improving of school achievement and self-care as possible.
\end{abstract}

Key Words: Intervention program, mother's knowledge \& practice, childhood cancer, children health status 


\section{INTRODUCTION}

The health status of children with cancer has been a subject of increasing interest in recent years, it were measured by general health ,mental health, functional status, limitation of activity, pain , anxiety and fear as result of cancer or its treatment (Ali, 2012). Also the Health Related Quality Of Life (HRQOL) focused on functional status and sense of well-being and uncompressed perception of both positive and negative aspects of physical, emotional ,social, cognitive functions , as well as the negative aspects of somatic discomfort and other symptoms produced by a disease and its treatment (Bondini et al., 2007; Yeh and Hung, 2011 ).

The assessment of health status is a great importance for pediatric cancer and their health care providers as a result of improvement of their survival rates and their quality of life (Yeh, 2010). The diagnosis and treatment of cancer is stressful and threatening experience that places children at significant risk for a range of short and long term physical, psychological, social, cognitive, and behavioral difficulties. Subsequently children with cancer usually fail to develop the autonomy and independency as result of nature of disease and its treatment. Mothers as primary care givers have dangerous role towards their children to provide the care and improve their health status and their quality of life, therefore, this study evaluates the effect of the intervention program for mothers about care of their children with cancer on their children health status(Radwan, 2009).

\section{AIM OF THE STUDY:}

Evaluate theeducational training program for mothers about care of their children with cancer and its effect on children health status.

\section{Research Hypothesis:}

Mother's knowledge \& practice of studied mothers and their children with cancer was improved after the implementation of the education program related to the care of their children and health status.

\section{SUBJECTS AND METHOD:}

Research Design: A quasi-experimental research design was utilized in the conduction of the study.

Setting: The study was carried out at pediatric inpatient and outpatient departments at Oncology Institute of Mansoura City.

Subjects: A convenient sample of 50 mothers and their children were used in the study according to inclusion criteria which weremothers should be accompanying child during chemotherapy at the study setting; children have any type of childhood cancer; children's age from 6 to 18 years; Children were from both genders; and they were undergoing chemotherapy and received at least two doses. 


\section{Tool for data collection:-}

Three different tools for data collection were used in this study as following:

\section{TOOL (1): Structured Interview Questionnaire Sheet:}

Upon inclusion in the study sample, each mother was interviewed individually. The questionnaire was designed by researcher after reviewing related to literature; it was designed in Arabic language to suit understanding of the study subjects.It contained two parts:

Part (1): Socio demographic characteristics of studied children such as age, gender, birth order and educational attainment.

Part (2): Socio demographic characteristics ofmother'ssuch as age, educational level, job status, residence and income, as well as family size.

\section{TOOL (2): Assessment of mother's knowledge and reported practiceabout childhood cancer sheet,it included:}

Part (1): Assessment of mother's knowledge about childhood cancer

Thispartwas intended to assess mother's knowledge about cancer such as definition, risk factors, symptoms, and spread of disease, investigations, complications, and treatment. It also had questions for mother's knowledge about chemotherapy definition, duration, routes, action, and side effects, in addition to dealing with child under chemotherapy and the home precautions.

Scoring system: For each question, a correct answer was scored 1 and zero for correct answer. For each area of knowledge, the score items were summed-up and the total divided by the number of items, giving mean scores for the part. These scores were converted into percent score. Knowledge was considered satisfactory if percent score was $50 \%$ or more and unsatisfactory if less than $50 \%$.

Part (2): Assessment of mother's reported practice while caring of their children with cancer and undergoing chemotherapy.

Thistool was aimed at assessing mother's reported practice while caring for their children with cancer. It involved questions about the care provided for side effects as bone marrow, skin, and gastrointestinal, respiratory, urinary, muscle-skeletal, neurological and psychological side effects of chemotherapy. The mother was asked whether the steps of care for each side effect was done or not done.

Scoring system: The steps reported to be done were scored (1) and the items not done were scored (0) for each area, the scores of the items were summed-up and the total divided by the number of the items, giving a mean score for the part. These scores were converted into percent scores. The reported practice was considered adequate if the percent score was $60 \%$ or more and inadequate if less than $60 \%$.

\section{TOOL (3): The Pediatric Health Status Assessment Tool}

This tool intended to assess the level of activity and health impairment of the child. It consisted of the following parts: 


\section{Part (I): Lansky Play Performance Scale}

This scale assesses the performance status and activity of daily living of children used this tool. It was initially developed by Lansky (1997), and modified by Yaris et al (2001) and Ali (2012). The scale and was consisted of eleven levels or grades ranging from 0 to $100 \%$.

\section{Part (2): Health related Quality of Life}

This part of the tool was used to assess the health related quality of life of the child with cancer. It was initially developed by Verny(2003), and modified by Radwan (2009) then by researcher. The tool consists of 49 statements assessing impairment in physical, psychological, social, school achievement, and self-care areas.

\section{Method of study}

- An official permission was obtained from the directors of oncology institute in Mansoura city through an official formal letters from the dean of The Faculty of Nursing Port Said University.

- The tools were tested for their content validity and clarity by seven experts in nursing and medical pediatrics and oncology for face and content validation. The tools were then adjusted based upon their recommendations.

- Informed consent was obtained from each mother in the study after explaining its purpose and importance. Confidentially of the information was assured by the researcher.

- A pilot study was carried out after review of data collection tools by seven experts. It was applied on $10 \%$ of study sample (five mothers and their children with cancer attending the Oncology Institute in Mansoura City). The purposes of the pilot study were to test the applicability, clarify, and feasibility of the data collection tools.

- The actual study was conducted through four phases: assessment phase, program development phase, implementation phase and evaluation phase.

Assessment Phase (Pretest): This phase-involved preparation of the tools and assessment of the mothers' knowledge and practice regarding the care of their children with cancer undergoing chemotherapy and assessment children health status. After obtaining the mother's consent, the researcher conducted an individual interview with her in the study setting according to hospital policy .Each interview questionnaire took approximately 35 to 40 minutes using an individual interview questionnaire form.

Planning Phase: the researcher developed the educational program using the baseline information gathered in the assessment phase.The program aimed at improving mothers' knowledge and reported practice for provision of care to their children with cancer and evaluate the effectiveness of the program on children health status. The program included materials to improve mothers' knowledge regarding the definition of childhood cancer, its types, clinical manifestations, predisposing factors, investigations and treatment. It also covered instructions concerning the preparation of the child before, during, and after chemotherapy doses and the precautions to protect other children at home. The program also included reported practice related to 
care of chemotherapy side effects such as disturbances of bone marrow, gastrointestinal tract, respiratory system, hair and skin, urinary system, musculoskeletal system, nervous system, and psychological impairment.

Implementation phase: The implementation of the program was carried out at the inpatient and out-patient departments in the study setting. The program was administered in five sessions; the duration of each session lasting from 45 to 60 minutes. The sample of mothers was divided into 10 groups; each session of the program included five mothers. At the beginning of the first session of the program, mothers were oriented about program objectives, contents, and procedures. The program was implemented two days per week during a period of 6 months from November 2013 to April 2014.

The educational program was presented in a clear and concise form, following the principles of adult learning, focusing on interactive learning and active participation. It was implemented using different teaching methods such as short lectures, group discussion, practice, demonstration and re-demonstration. In addition, different audiovisual materials were used as pamphlets, pictures, posters and video to facilitate the teaching of each topic.

Evaluation Phase: The effectiveness of the program was based on assessing the improvement in mother's knowledge and reported practiceand of children's health status.. This was achieved through comparing the pre-test with post- test immediately done after the implementation of the program, and the follow- up test carried out three months later.

Statistical analysis of data:Up completion of data collection, variables included in the structured interview sheet, were coded prior to computerized data entry. The raw data were coded and transformed into coding sheets. The results were checked. Then, the data were entered using SPSS 20.0 statistical software package. Output drafts were checked against the revised coded data for typing and spelling mistakes. Finally, analysis and interpretation of data were conducted.

\section{RESULTS:}

Table (1) demonstrates socio-demographic characteristics of the studied children with cancer, children's age ranged between six and sixteen years, with more males $(60.0 \%)$.Slightly more than one-third of them $(42.0 \%)$ were firstborn. As for their educational level, approximately two-thirds $(68.0 \%)$ were in the primary level, whereas only $4.0 \%$ were in secondary education.

Table (2) shows socio-demographic characteristics of studied mothers, it illustrated that mother's age ranged between 25 and 55 years, with median 35 . They mostly had secondary education (64.0\%).As, the family size ranged between three and six members, with median five, and the great majority $(92.0 \%)$ having insufficient income. 
Figure (1): shows total mother's knowledge about childhood cancer throughout the study phases. It clarified that $14 \%$ of the studied mothers had satisfactory knowledge pre the intervention, while post the intervention immediately and at follow up, majority of the studied mothers had satisfactory knowledge (96\%, 94\%) respectively. There was statistically significant improvement $(\mathrm{p}<0.001)$.

Figure (2): illustrates total reported practice of the studied mothers related to their children care of chemotherapy side effects throughout the study phases.it clarified that only $34.0 \%$ of the studied mothers had total adequate reported practice at the preintervention phase. Meanwhile, majority of them(96.0\%) had adequate reported practice at the post- intervention and $90.0 \%$ of them at the follow up phase. These improvements were statistically significant $(\mathrm{P}<0.001)$.

Table (3): shows Performance and activity score of the studied children according to Lansky- Scale pre the intervention and at follow - up.Illustrates performance and activity score of the studied children with cancer according to Lansky- performance Scale pre the intervention and at follow -up. It pointed that a slight increase children's activity score in the follow up phase compared with pre- intervention phase. However, this difference was not statistically significant.

Table (4): illustrates health impairment among studied children pre the intervention and at follow-up phase. The follow up phase showed statistically significant decreases in the percentages of children having severe physical $(\mathrm{p}=0.04)$, psychological $(p=0.03)$, and social $(p=0.03)$ health problems. On other hand, no significant changes were revealed in the cognitive/school or self -care impairment.

Figure (3): shows total health impairment among studied children pre the intervention and at follow-up, it demonstrated improvement of children's health impairment at follow-up compared with pre-intervention phase. The percentage of children with severe impairments decreased from $60 \%$ to $40 \%$ respectively. 
Table (1): Percent distribution of studied children related to socio-demographic characteristics

\begin{tabular}{|l|l|l|}
\hline Socio-demographic Characteristics & $\mathbf{N}=\mathbf{( 5 0 )}$ & \% \\
\hline Age (years): & 34 & \\
$<12$ & 16 & 68.0 \\
$12+$ & $6.0-16.0$ & 32.0 \\
\hline Range & $9.5 \pm 3.2$ \\
\hline Mean \pm SD & 8.5 & \\
\hline Median & & 60.0 \\
\hline Gender: & 30 & 40.0 \\
Male & 20 & \\
Female & & 42.0 \\
\hline Birth Order: & 21 & 40.0 \\
First & 20 & 12.0 \\
Second & 6 & 6.0 \\
Third & 3 & \\
Fourth & & 68.0 \\
\hline Level of Education: & 34 & 28.0 \\
Primary level & 14 & 4.0 \\
Preparatory level & 2 & \\
Secondary level & & \\
\hline
\end{tabular}


Table (2): percent distribution of studied mothers related to Socio-demographic characteristics.

\begin{tabular}{|c|c|c|}
\hline Socio-demographic Characteristics & $(n=50)$ & $\%$ \\
\hline $\begin{array}{l}\text { Mothers Age (years): } \\
<35 \\
35+\end{array}$ & $\begin{array}{l}22 \\
28\end{array}$ & $\begin{array}{l}44.0 \\
56.0\end{array}$ \\
\hline Range & $25.0-55.0$ & \\
\hline Mean \pm SD & $35.6 \pm 7.4$ & \\
\hline Median & 35 & \\
\hline $\begin{array}{l}\text { MothersEducation: } \\
\text { Basic education ( primary\& preparatory) } \\
\text { Secondary education } \\
\text { University education }\end{array}$ & $\begin{array}{l}3 \\
32 \\
15 \\
\end{array}$ & $\begin{array}{l}6.0 \\
64.0 \\
30.0 \\
\end{array}$ \\
\hline $\begin{array}{l}\text { Mother'sjob: } \\
\text { House wives } \\
\text { Employed mothers } \\
\end{array}$ & $\begin{array}{l}45 \\
5 \\
\end{array}$ & $\begin{array}{l}90.0 \\
10.0 \\
\end{array}$ \\
\hline $\begin{array}{l}\text { Residence: } \\
\text { Urban } \\
\text { Rural }\end{array}$ & $\begin{array}{l}26 \\
24\end{array}$ & $\begin{array}{l}52.0 \\
48.0\end{array}$ \\
\hline $\begin{array}{l}\text { Family size } \\
<5 \\
5+\end{array}$ & $\begin{array}{l}8 \\
42 \\
\end{array}$ & $\begin{array}{l}16.0 \\
84.0\end{array}$ \\
\hline Range & $3.0-6.0$ & \\
\hline Mean \pm SD & $5.0 \pm 0.6$ & \\
\hline Median & 5.00 & \\
\hline $\begin{array}{l}\text { Income } \\
\text { Sufficient } \\
\text { Insufficient }\end{array}$ & $\begin{array}{l}4 \\
46\end{array}$ & $\begin{array}{l}8.0 \\
92.0\end{array}$ \\
\hline
\end{tabular}

(*) Statistically significant at $p<0.05$

Figure (1): Total mother's knowledge score about childhood cancer throughout the study phases.

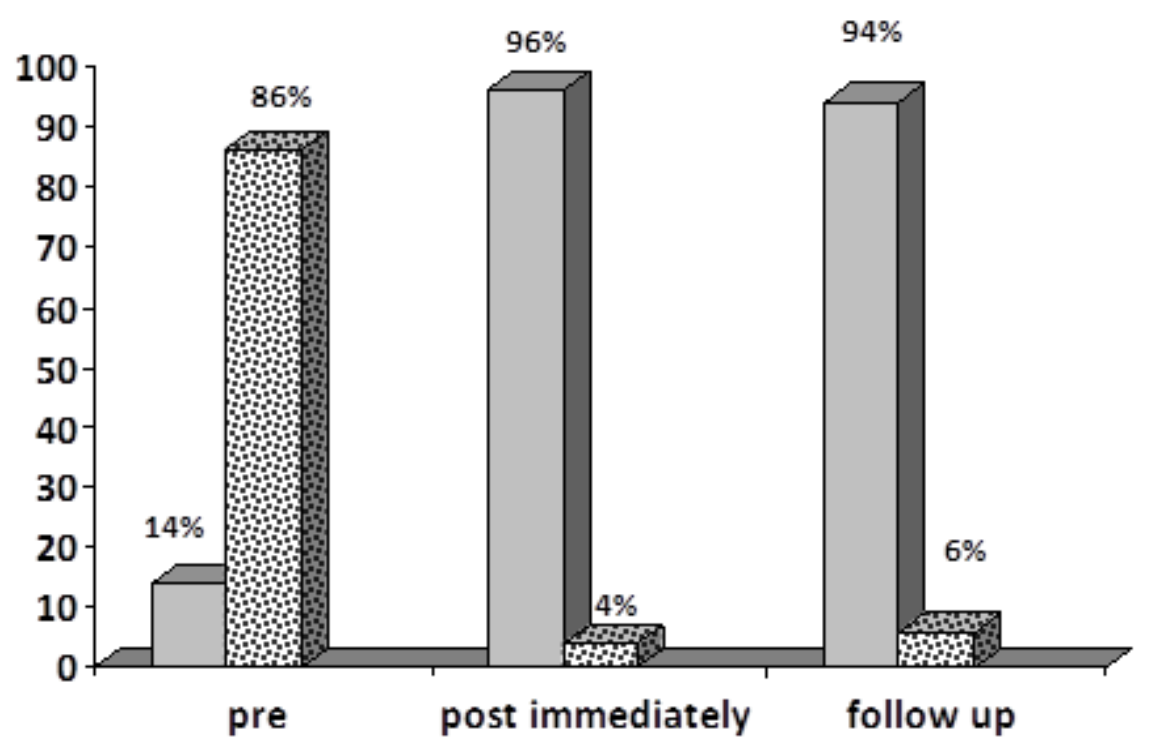

Unsatisfactory $\mathrm{X}$ satisfactory 
Figure (2): Total reported practice score of the studied mothers related to their children care of chemotherapy side effects throughout the study phases.

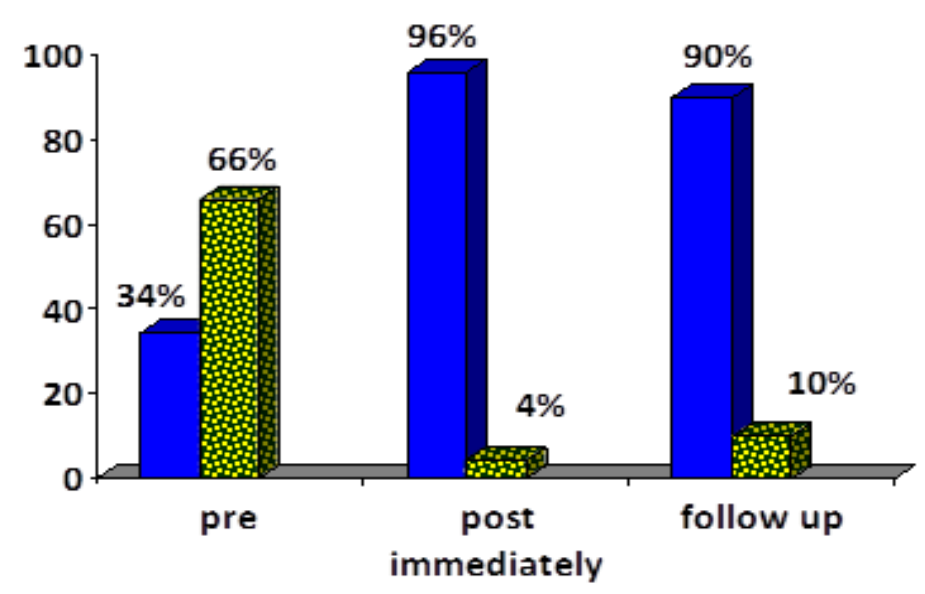
A dequate
Inadequate
血国

Table (3): Percent distribution of the studied children related to practice and activity score using Lansky- Scale pre the intervention and at follow - up.

\begin{tabular}{|c|c|c|c|c|c|c|}
\hline \multirow{3}{*}{$\begin{array}{c}\text { Activity and } \\
\text { performance scale }\end{array}$} & \multicolumn{4}{|c|}{ Program phases } & \multirow{3}{*}{$\begin{array}{c}\text { Mann } \\
\text { Whitney } \\
\text { Test }\end{array}$} & \multirow{3}{*}{ p-value } \\
\hline & \multicolumn{2}{|c|}{ Pre } & \multicolumn{2}{|c|}{ FU } & & \\
\hline & No. & $\%$ & No. & $\%$ & & \\
\hline \multicolumn{7}{|l|}{ Activity score : } \\
\hline+70 & 34 & 68.0 & 36 & 72.0 & & \\
\hline$<70$ & 17 & 32.0 & 14 & 28.0 & & \\
\hline Range $\pm \mathrm{SD}$ & \multicolumn{4}{|c|}{$10.0-90.0$} & & \\
\hline Median & \multicolumn{4}{|c|}{$65.8 \pm 20.6$} & 0.19 & 0.66 \\
\hline
\end{tabular}

Table (4): percent distribution of studied children related to health impairment pre the intervention and follow-up.

\begin{tabular}{|c|c|c|c|c|c|c|}
\hline \multirow{3}{*}{ Severe impairment of: } & \multicolumn{4}{|c|}{ Program phases } & \multirow{3}{*}{$\begin{array}{l}X^{2} \\
\text { Test }\end{array}$} & \multirow{3}{*}{ p-value } \\
\hline & \multicolumn{2}{|l|}{ Pre } & \multicolumn{2}{|l|}{ FU } & & \\
\hline & No. & $\%$ & No. & $\%$ & & \\
\hline Physical health impairment & 33 & 66.0 & 23 & 46.0 & 4.06 & $0.04^{*}$ \\
\hline Psychological health impairment & 19 & 38.0 & 9 & 18.0 & 4.06 & $0.03 *$ \\
\hline Social health impairment & 32 & 64.0 & 13 & 26.0 & 4.06 & $0.03 *$ \\
\hline Impairment of cognitive /school achievement. & 38 & 76.0 & 42 & 84.0 & 1.00 & 0.32 \\
\hline Self-care & 8 & 16.0 & 8 & 16.0 & 0.00 & 1.00 \\
\hline
\end{tabular}


Figure (3): Total health impairment among studied children pre the intervention and at follow-up.

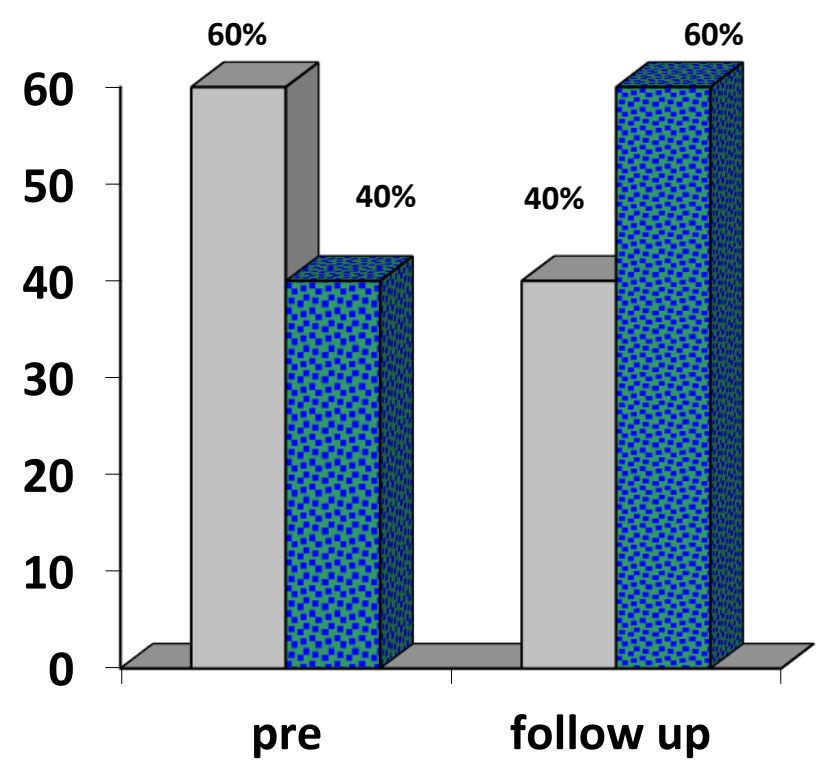

Mild/ moderate

$\square$ Severe

\section{DISCUSSION:}

Mothers of children with cancer may suffer from various forms of distress in regards to the child's illness, side effects of treatment. They have serious duties and roles toward their children because children with cancer often fail to develop independency and autonomy as result of their illness nature, treatment and complication of disease. Meanwhile, mothers as primary care givers have roles to promote the care of their children and to improve their quality of life (Roddenberry \& Renk, 2008; Thompson et al., 2009). The present study was carried out to evaluate the intervention program for mothers about care of their children with cancer and its effect on their children health status.

The implementation of the current study intervention led to significant improvements in mothers' knowledge. This was noticed in most areas related to cancer itself and chemotherapy. Thus, by the end of the intervention, majority of the studied mothers had satisfactory knowledge, which points to the effectiveness of the educational program in achieving its first specific objective. The present study findings are in agreement with those ofRodrigues et al. (2010) who demonstrated a lack of mothers' informationabout childhood cancer, and recommended an educational interventionbased on identification of mothers' information needs during thehospitalization with their children in order to understand the disease natureto be able to support their children .On the same line, Juma et al. (2010)found that the majority of the mothers had no knowledge of cancer and chemotherapy in children before implementing their program. After theeducational program, 94\% of the mothers had correct knowledge aboutchildhood cancer and chemotherapy. Similar successes of educationalinterventions targeting the parents and siblings of children 
with cancerwere reported from Iran (Hashemi \& Sokrpour, 2010), Malaysia (Othmanet al., 2010), Sweden (Ringner et al., 2015) and (Lindsey et al., 2014).

After the implementation of the present study intervention, thepractices of the mothers improved in all the aspects tested. This wasassessed as self - reported practice. Hence majority of them had adequatereported practice at the post- intervention and $90.0 \%$ of them at the followup phase of the educational intervention demonstrated total adequate practices. This is undoubtedly attributed to the effect of the educationalprogram as shown by the results of the multivariate analyses, whichidentified the attendance of the program as the main and independent factorpositively influencing mothers' practice scores. The result is also in partialagreement with (Ringner et al., 2014)and (Gangane \&Sebastian, 2015) in Indiawhich demonstrated high satisfaction ofparents of children with cancer with personalized intervention.

The ultimate goal of the present study was to improve the health status of children with cancer through improving their mothers' knowledge and practices. The univariate analyses demonstrated slight improvement in children's activity scores following the intervention. However, the univariate analysis, there was a significant improvement in this score, and this was mostly induced by the attendance of the intervention program as the main significant positive predictor. The finding is in congruence with that of Elsayed \& Mahmoud (2012) who demonstrated significantly less restriction in children's performance of activities followingtheir educational intervention. A similar improvement in Lansky performance scale among children with cancer was shown following an intervention program in a study in India (Batra et al., 2014).

The current study also was aimed at improving the Health-Related Quality of Life (HRQL) of children suffering from cancer as a consequence of their mother's improved knowledge and practice. The results of the study actually demonstrated significant improvements in their HRQL, with decreases in their health impairments. This was noticed in most aspects of (HRQL), particularly regarding the physical, psychological, and social aspects. The findings are in agreement with the study done in Germany, which demonstrated significant improvements in the physical and psychological aspects of the (HRQL) of children with cancer (Beulerz etal., 2016). On the same line, a randomized clinical trial conducted in Hong Kong reported the effectiveness of a health education program in enhancing the physical, psychological, and social aspects of the HRQL of children with cancer; these improvements were sustained through a follow-up period of 18 months (Chung et al., 2015). Similarly, Gibson et al. (2010), who found that children with cancer engaging in regular physical activity after intervention showed better health outcomes, including better HRQL, better functional capacity and better mood states. However, a study carried out in the Netherlands demonstrated only a slight improvement in physical aspect of HRQL of children with cancer (Van Dijk-Lokkart et al., 2015). This lack of considerable improvement was attributed to the burden of attending the training program, whichnegatively influenced children's participation (VanDijk-Lokkart et al.,2014). 


\section{CONCLUSION:}

Based on the findings of the present study, it was concluded that knowledge and reported practice of the studied mothers related to care of their children with cancer and undergoing chemotherapy were deficient pre-the intervention program. While after developing educational intervention program to them, the results revealed that there were statistically significant improvement in mothers' knowledge and reported practice .Subsequently, this lead to a positive impact on their children's Health status (physical, psychological, and social status).

\section{RECOMMENDATIONS:}

Based on the findings of the present study, the following recommendations are to be considered: periodic or continuous training program should be applied for mothers and their child in the pediatric oncology departments to improve their knowledge and practice about childhood cancer which can improve children health status.

\section{REFERENCES:}

Ali, H. (2012): The effect of educational intervention on maternal management of children with cancer and their quality of life. Published doctorate thesis, Faculty of Nursing Banha University.P.13.

Batra, P., Kumar, B., Gomber, S.\& Bhatia, M.( 2014): Assessment of quality of life during treatment of pediatric oncology patients .Indian J Public Health; 58(3):168-73.

Beulertz, J., Prokop, A., Rustler, V., Bloch, W., Felsch, M.\& Baumann F. (2016): Effects of a 6-Month, Group-Based, Therapeutic Exercise Program for Childhood Cancer Outpatients on Motor Performance, Level of Activity, and Quality of Life. Pediatric Blood Cancer. 63(1):127-32.

Bondini, S., Kallman, J., Dan, A., Yonoszai, Z., Ransey, L., Nader, F. \& Zobair, M. (2007): Health related quality of life with chronic disease. Nursing research journal; 21(6): 111 .

Chung, O., Li, H., Chiu, S., H, K., Lopez, V. (2015): Sustainability of an Integrated Adventure-Based Training and Health Education Program to Enhance Quality of Life Among Chinese Childhood Cancer Survivors: A Randomized Controlled Trial. Cancer Nurs 38(5):366.

Elsayed, E. and Mahmoud, F. (2012): Outcome of enhancement of maternal knowledge and practice on health status of their children with cancer. Journal of American Science; 8(3): 322-333. Available at Http://www.americanscience. Org.

Gangane, N.\& Sebastian,M.(2015): Women's Knowledge, Attitudes, and Practices about Breast Cancer in a Rural District of Central India. Asian Pac J Cancer Prev. 2015; 16(16):6863-70. 
Gibson, F., Aldiss, S., Horstman, M., Kumpunen, S. and Richardson, A. (2010): Children and young people's experiences of cancer care: A qualitative research study using participatory methods. Int J Nurs Stud.; 47:1397-407.

Hashemi, F., Shokrpour, N. (2010): The impact of education regarding the needs of pediatric leukemia patients' siblings on the parents' knowledge and practice. Health Care Manag (Frederick). Jan-Mar; 29(1):75-9.

Juma, M., Otiti, S. and Mwanda, W. (2010): Childhood cancer; mothers awareness and understanding of causative factors in Chakol division of district western province of Kenya. Kenya National Hospital. Nairobi Medical Training College; 21(6):151.

Lansky, S., (1997): The Measure of Performance in Childhood Cancer, Cancer; 60: 1651-6.

Lindsey, R., Shroyer, J., Pashler, H., Mozer, M. (2014): Improving students' longterm knowledge retention through personalized review. Psychol Sci.; 25(3):639-47.

Othman, A., Blunden, S., Mohamad , N., Mohd, Z.\& Osman, Z. (2010): Piloting a psycho-education program for parents of pediatric cancer patients in Malaysia. Psycho-oncology;19(3):326-31.

Radwan, A. (2009): Quality of life in newly diagnosed children suffering from cancer. Unpublished Master Thesis, Faculty of Nursing, Ain Shams University; P.p. $12,30,32,35$.

Ringnér, A., Björk, M., Olsson, C.\& Graneheim, U. (2015): Person-centred information to parents in pediatric oncology (the PIFBO study): A study protocol of an ongoing RCT. BMC Nurs; 14:69.

Ringnér, A., Karlsson, S.\& Graneheim, U.(2014): A person-centred intervention for providing information to parents of children with cancer. Experiences and effects. Eur J Oncol Nurs ; 19(3):318-24.

Roddenberry, A. and Renk, K. (2008): Quality of life in pediatric cancer patients: The relationships among parents' characteristics, children's characteristics, and informant concordance .Journal of Child and Family Studied, 17(3); 402, 426.

Rodrigues, L., Margareth, A., Luciana, P. and Alves, M. (2010): Uncertainties in the childhood cancer understanding the mother's needs. Escola. Anna Ney; 14(2): $301-$ 308.

Thompson, S., Leigh, C. and Chistensen, R. (2009): Immediate neuro cognitive effect of inetny, Lphenidate on Learning - impaired survivors of childhood cancer Journal of Clinical Oncology; P.p. $1802-1808$.

van Dijk-Lokkart, E., Braam, K., Dulmen, E., Kaspers G., Takken T., Grootenhuis M., Streng I., Bierings M., Merks J., van den Heuvel-Eibrink M., Veening M.\& Huisman J. (2014): Effects of a combined physical and psychosocial intervention program for childhood cancer patients on quality of life and psychosocial functioning: resultsof the QLIM randomized clinical trial. Psychooncology. 
Varni, J. (2003): Pediatric quality of life, life inventory, Cancer Nursing Journal ; 20 (3):120-132.

Yaris, N., Yavus, M. and Okten, A. (2001): Assessment of quality of life in pediatric cancer patient at diagnosis and during therapy. Turkish Journal Cancer; 31(4), 139149.

Yeh, C. and Hung, L. (2011): The quality of life for cancer children in Taiwan, Psycho-Oncology Journal; Vol (13): P. 161 - 170.

Yeh, C. (2010): Evaluating quality of life in children with cancer, using children's self-reports and parent proxy report, Nursing Research Journal; vol. 54: 354 - 362. 
تأثير برنامج تعليمى تدريبى للأمهات حول رعاية اطفالهن المصابين بالسرطان وتاثيره علي حالتهم اطفالهن الصحية

دعاء بقيج أنور عقل -6، نبيله حسن على عبد الله ، أمل أحمد خليل مرسى ، محمد محمد أحمد المزاحى

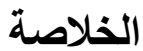

تهدف هذه الدراسة شبه التجرييية إلي تقييم برنامج تداخلى للأمهات حول رعاية أطفالهن المصابين بالسرطان و الخاضعين للعلاج الكيماوي وتاثيره علي حالتهم الصحية . أجريت هذه الدراسة في معهد الاورام بالمنصورة في العيادات الخارجية وقسم الداخلي للاطفال وشملت العينة ــ من الأمهات و أطفالهن المصابين بالسرطان

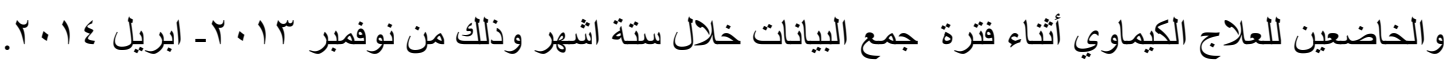
كما استخدمت ثلاثة أدوات لجمع البيانات من الأمهات، الأداة الأولى وهي استمارة استبيان مصممة بواسطة

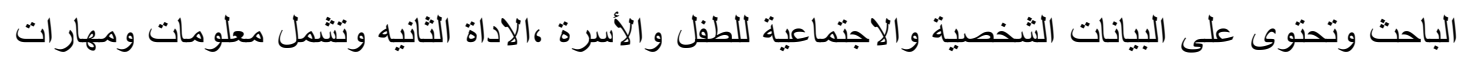
الامهات المرتبطة بمرض السرطان والعلاج الكيماوي ،اما الاداه الثالثة فهي تثنمل مقياس الحالة الصحية للطفل. ولقد أوضحت الدراسة ان ؟ ا \% فقط من الامهات لديهن معلومات كافية قبل تلقي البرنامج التعليمي بينما الغالبية العظمي منهمن اصبحن لايهن معلومات كافية سواء بعد تلقي البرنامج مباثرة او بعد ثلاثة اشهر، كما

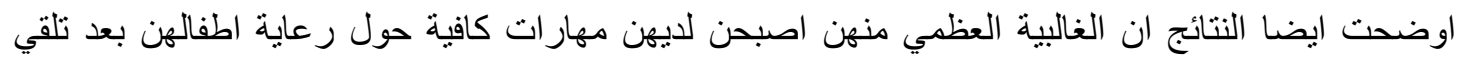

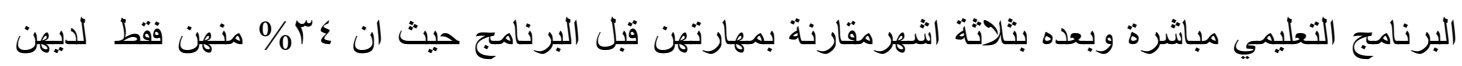
مهار ات حول رعاية اطفالهن .كما اوضحت النتائج ايضا وجود تحسن ذو دلالة احصائية مرتبطة بمعلومات الامهات ومهارتهن حول رعاية اطفالهن الخاضعين للعلاج الكيماوي بعد البرنامج مباثرة و ايضـا بعده بثلاثة اشهر مقارنة بمعلوماتهن قبل البرنامج التعليمي .وايضا اسفرت تللك النتائج عن وجود تحسن ذات دلالة احصائية للحالة الصحية للاطفال وجودة حياتهم .لذا فقد اوصت الدر اسة الي اقامة بر امج تعليمية بصفة مستمرة لامهات الاطفال الذين يعانون من السرطان وتكرار هذا البحث على عينة كبيرة و في أماكن مختلفة في مصر وجعل

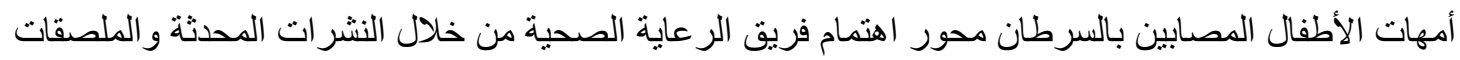
و الكتيبات التي تساعد علي تحسين معلوماتهن ومن ثم تحسين الحالة الصحية لاطفالهن .

الكلمات المرشدة : برنامج تعليميـ معلومات ومهار ات الامهات ـ سرطان الطفولة ـ علاج كيماوي 